tiv a rew bars, 8vo, Čloth,

\title{
LECTURES ON MENTAL DISEASES.
}

\author{
By W. H. O. SANKEY, M.D. LoND.
}

John Churchill and SONS, New Burlington Street.

Just published, seventh edition, fcap. $8 \mathrm{vo}, 2 s .6 d$.

HEALTHY SKIN AND HAIR: a Popular'Treatise on their Preservation and Management. By ERASMUS WILSON, P.R.S.

JOHN Churchill aNd SONS, New Burlington Street.

Just published, price $1 s$.

THE ALKALINE PERMANGANA'TES, and their Medicinal Uses. By JOHN MUTER, late Assistant-Demonstrator in Chemistry in the Andersnuian University, Glasgow.

JOHN CHURCHILl AND SONS, New Burlington Street.

Just published, price 18.

ON A NEW METHOD OF APPLYING REMEDIAL AGENTS to the CAVITY of the TYMPANUM. By EDWARD BISHOP, M.D., Surgeon to the Metropolitan Infirmary for Diseases of the Ear.

JOHN CHURCHILL AND SONS, New Burlington Street.

Eighth Edition, with Notes and Annotations by Sir Charles Locock, Bart., M.D., F.R.S., fcap. $8 \mathrm{vo}, 2 s .6 d$.

ADVICE TO A MOTHER ON THE MANAGEMEN'I OF HER CHILDREN, AND ON THE TREATMENT, ON THE MOMENT, OF SOME OF THEIR MORE PRESSING ILLNESSES AND ACCIDENTS. By PYE HENRY CHAVASSE, F.R.C.S.

By the same Author, seventh edition, fcap. 8 vo, $2 s, 6 d$.

ADVICE TO A WIFE ON THE MANAGEMENT OF HER OWN HEALTH, and on the Treatment of some of the Complaints incidental to Preguancy, Lahour, and Suckling. With an Introductory Chapter especially addressed to a Young Wife.

JOHN ChURCHILL AND SONS, New BurLington Street.

With Engravings, post 8vo, cloth, 7s. 6 d.

LECIURES ON EPILEPSY, PAIN, PARALYSIS, AND CERTAIN OTHER DISORDERS OF THE NERVOUS SYSTEM. Delivered at the Royal College of Physicians in London. By CHARLES BLAND RADCLIFFE, M.D., P.R.C.P., Pliysician to the Westminster Hospital, aud to the National Hospital for the Paralysed and Epileptic.

jOHN CHURChill AND SONS, New Bureington Stregt. 
$8 \mathrm{ro}$, cloth, $10 s .6 d$.

THE MEDICAL DIRECTORIES FOR 1866, giving 1000 pages of Statistical and General Information relative to the Medical Profession in the United Kingdom. JOHN CHURCHILL AND SONS, New Burlington Strekt.

Now ready, crown 8 vo, price $2 s .6 d$.

IIIE YEAR-BOOK OF PHARMACY FOR 1865: being a Practical Summary of Researches in Pharmacy, Materia Medica, and Pharmaceutical Chemistry for 1865 . Edited by CHARLES WOOD, F.C.S., and CHARLES SHARP, both of the Pharmaceutical Society.

JOHN ChurChill aND SONS, New Burlington Street.

Fcap. $8 \mathrm{vo}, 2 s .6 d$.

IHE SURGERY OF THE RECTUM. With Cases illustrating the Treatment of Hæmorrhoids and Prolapsus by the Improved Clamp. (Lettsomian Lectures.) By HENRY SMITH, F.R.C.S., Assistant-Surgeon to King's College Hospital, Vice-President of the Medical Society of London. JOHN ChurChILl AND SONS, New Burlington Stregt.

\section{Pulvis Jacobi Ver., Newbery's.} FRANCIS NEWBERY AND SONS,

45, St. Paul's Churchyard.

THE YEEBLE-MINDED, IMBECILE, AND IDIOTIC.

Just published, in 1 vol., crown $8 \mathrm{vo}, 5 s$.

MANUAL FOR THE CLASSIFICATION, TRAINING, AND EDUCATION OF THE FEEBLE-MINDED, IMBECILE, AND IDIOTIC. By P. MARTIN DUNCAN, M.B. Lond., F.G.S., F.A.S.L., Honorary Consulting Surgeon to the Eastern Counties Asylum for Idiots and Imbeciles; and WILLIAM MILLARD, Superintendent of the Eastern Counties Asylum for Idiots and Imbeciles.

London: LONgmans, GReEN, AND CO., Paternoster Row.

\section{THE NEW SYDENHAM SOCIETY.}

From the prosperous state of the Society's Funds, the Council confidently hopes to be enabled to issue at least 3 Vols. and a Fasciculus for the current year's Subscription. Among the works in preparation is-

GRIESINGER'S MANUAL OF MENTAL DISEASES.

Translated by Dr. LOCKHART ROBERTSON and Dr. RUTHERFORD.

Copies of Annual Report and all particulars, on application to the Society's Agent, Mr. H. K. I.EWIS, 136, Gower Street. 